\title{
Atlantis
}

Critical Studies in Gender, Culture \& Social Justice

Études critiques sur le genre, la culture, et la justice

\section{Film Review: The Fruit Machine}

\section{Lynne Gouliquer, Carmen Poulin and P-SEC Research Group}

Volume 41, Number 2, 2020

Gender and the Canadian Armed Forces

URI: https://id.erudit.org/iderudit/1076203ar

DOI: https://doi.org/10.7202/1076203ar

See table of contents

Publisher(s)

Mount Saint Vincent University

ISSN

1715-0698 (digital)

Explore this journal

Cite this review

Gouliquer, L., Poulin, C. \& P-SEC Research Group (2020). Review of [Film

Review: The Fruit Machine]. Atlantis, 41(2), 95-98.

https://doi.org/10.7202/1076203ar

\section{Article abstract}

The following is a review of The Fruit Machine documentary film directed by Sara Fodey. This documentary sheds light on a dark period in Canadian history. Using the testimonials of survivors and historical expert, The Fruit Machine film illustrates how a democratic state could legally wage a discriminatory campaign against its own citizens whose only crime was being (or suspected to be) "homosexual." For fifty years, Canadian state institutions hunted down and interrogated thousands of individuals suspected of homosexuality. This film is a must see.
All Rights Reserved @ Lynne Gouliquer, Carmen Poulin, P-SEC Research Group, 2020
This document is protected by copyright law. Use of the services of Erudit (including reproduction) is subject to its terms and conditions, which can be viewed online.

https://apropos.erudit.org/en/users/policy-on-use/ 


\section{Special Issue: Gender and the Canadian Armed Forces \\ Film Review}

\section{The Fruit Machine}

Lynne Gouliquer is an associate professor of Sociology at Laurentian University (Sudbury, ON, Canada). She is a Banting and an O'Brien fellow. Her research focuses on the sociology of institutions and marginalisation, as they apply to groups such as women in the Canadian military, LGBTQ2IA+ soldiers and their families, women firefighters, oldest-older adults living in place, and Métis people. She is a military survivor/veteran of the LGBT Purge campaign and a two-spirit Métis. She is the co-founder of the Psycho-Social Ethnography of the Common Place (PSEC) methodology and co-director of the P-SEC Research Group (https://p-sec.org/).

Carmen Poulin is the Associate Dean of Arts (Research \& Graduate Studies) and a professor in Psychology and Gender \& Women's Studies at the University of New Brunswick, Canada. Her research focuses on the impact of social practices and ideologies on women and marginalised groups' daily lives. In particular, she is interested in the experiences of women and marginalised groups (e.g., women firefighters, LGB$\mathrm{TQ}+$ in the military) within men-dominated organisations. She is the co-developer of the Psycho-Social Ethnography of the Common Place (P-SEC) methodology and co-director of the P-SEC Research Group (https://p-sec.org/)

The P-SEC Research Group is a multi-disciplinary group at the time comprised of Alissa Moore, Jennifer McWilliams, Lena Mohamad, Sandrine Poulin, Ursula Cafaro, Brandon Portelance, Sophia Konerman, and Gabriellange Parent.
Film under Review: The Fruit Machine. 2018. Directed by Sarah Fodey. Produced by Han Nguyen, Derek Diorio, and Sarah Fodey. SandBay Entertainment. Ottawa and Toronto.

Available at https://www.tvo.org/video/documentaries/ the-fruit-machine-feature-version

Abstract: The following is a review of The Fruit Machine documentary film directed by Sarah Fodey. This documentary sheds light on a dark period in Canadian history. Using the testimonials of survivors and historical experts, The Fruit Machine film illustrates how a democratic state could legally wage a discriminatory campaign against its own citizens whose only crime was being (or suspected to be) "homosexual." For fifty years, Canadian state institutions hunted down and interrogated thousands of individuals suspected of homosexuality. This film is a must-see.

Keywords: discrimination, gender, investigations, LGBT Purge campaign, military, prisoners of war, The Fruit Machine 
$\mathrm{T}$ he Fruit Machine is a Canadian documentary film written and directed by Sarah Fodey and released in 2018. It presents as something between a documentary and a spy movie, yet it is one hundred percent based in reality - a Canadian reality. This film details how Canadian soldiers, civil servants, and police officers serving in our national institutions - the Canadian Armed Forces (CAF), Civil Service, and Royal Canadian Mounted Police (RCMP)—were investigated, intimidated, and interrogated like prisoners of war from the 1950s to the 1990s. Using the testimonies of numerous survivors and subject-matter experts (e.g., journalists and academics), the film illustrates how thousands of people lost their job, their health, their confidence, their future, their dream, and their trust in the Canadian state. The Fruit Machine tells the story of what is now known as the Canadian LGBT Purge campaign and unveils a piece of Canadian history that has remained invisible and unaddressed for many years.

The first half of The Fruit Machine focuses primarily on the historical context of the LGBT Purge, including the Cold War. Intertwined with this historical section are the stories of a number of men Civil Service Purge survivors who were investigated and lost their jobs and the story of a retired Drag Queen performer who worked at an infamous gay bar in Ottawa during the Purge campaign. Through this particular telling of history, the RCMP is portrayed as the guardian of national security as well as the main perpetrator of the investigations and terminations. The producers anchor the film in the late 1940 s to the 1970 s, a time when governments demagogued that homosexuality was one of the western world's greatest enemies. The belief that communist enemies (i.e. the Russians) could blackmail "homosexuals" (aka "sexual criminal deviants") legitimised an intrusion into the private lives of Canadians. In particular, the military's Special Investigative Unit (SIU) and the RCMP targeted and hunted down members of the CAF, Civil Service, and RCMP suspected of homosexuality.

The second half of the documentary focuses predominantly on the stories of women military Purge survivors. The producers excel in capturing the emotionally powerful testimonies of sexual violence, intimidation, and torturous interrogations. They skilfully illustrate the depth of the harm perpetrated and the young lives left in ruins. The fact that the documentary is dominated by the testimonies of military Purge survivors is not explained in the film, but it is not surprising. The CAF continued the Purge campaign until 1992, years after the RCMP and Civil Service had stopped their own Purge (Poulin, Gouliquer, and McCutcheon 2018; Poulin and Gouliquer 2012). While numerous cases were brought to the courts, the most famous and determining one was that of Michelle Douglas (Park, 1994), which ended the military's ability to officially discriminate.

When putting together a documentary, two important and related constraints are the budget and length of the film, both of which necessitate strategic choices. You need to tell the story, do it convincingly, and in the shortest amount of time possible. The producers meet this challenge admirably, but it results in an unfortunate gender division: The subject-matter experts chosen to provide the historical backdrop and analysis are mostly men. Most of the personal stories from the Purged men are interwoven into this telling of the Purge's history. In contrast, in the second half of the film, women dominate the screen as they tell their intensely emotional and devastating stories. Through this sequence in the film, men appear mostly agentic, less emotional, and in control while the women appear more emotional, passive, and non-agentic. These characteristics are often (problematically) associated with masculinity and femininity, respectively (Gouliquer 2011). The experts are convincing and so are the survivors but a byproduct is the impression of a gendered and patriarchal heteronormative script.

The decision to devote as much time to the historical overview of the Cold War, the RCMP, and the development of a device to purportedly detect homosexuality, The Fruit Machine, left little space for a more inclusive history of the fifty years during which the Purge campaign raged in Canada. Paring down the historical overview, however, would have turned the documentary into more of a military story, given that by the mid 1980s, the military was the only institu- 
tion purging "homosexuals." Although the story of the development of a machine to detect homosexuality is riveting, it is worth noting that this machine was a failure and was used for only about three years. Nonetheless, the "fruit machine" device story captures the imagination and symbolically signifies how the Canadian government's machinery was mobilised to detect and eliminate homosexuality from its ranks.

The documentary missed an opportunity to critically examine how federal institutions used the process of othering sexual minorities for strategic ends. Stoking the fears of all government employees - soldiers, police officers, and civil servants-about the manufactured threat posed by homosexuality served to create an enemy within, which helped to maintain the readiness of these institutions and their personnel for war. As is noted in the film, no "homosexuals" were ever found to have been blackmailed by Russian communist intelligence. Rather, the tactics used by the RCMP and the military's SIU to extract names and confessions, including blackmailing and lying, were a means to break the morale of suspected "homosexuals" and practice interrogation skills on these substitute "prisoners of war" (Poulin 2001; Poulin, Gouliquer, and Moore 2009).

As The Fruit Machine illustrates, there were many instances of sexual harassment and assault within the Canadian military. Yet, as noted by military Purge survivor Patti Grey in the documentary, the assaults were ignored because the military police were "too busy chasing queers" and perpetrators were protected because "boys will be boys." The producers could have strengthened the film by providing insight on how lesbians' sexual independence and the association of femininity with weakness, gay men, and women's gender all posed a threat to the hegemonic hypermasculine warrior soldier image (see Blair and Hoskin 2015; Hoskin 2017 for their discussion on femininity). An essential feature of the Purge campaign is that it was, foremost, a deeply misogynist initiative that tried to eradicate the feminine/femininity within the soldier, civil servant, and police officer (Gouliquer 2000, 2011). Omitting analysis of these interlocking factors means that the links among sexual violence, hetero- normativity, femmenegativity, and hegemonic masculinity involving gender and sexual minorities in these environments remain unexplored and unchallenged. While the documentary makes visible a tragic part of Canadian history, one wonders if it has disrupted the status quo or if it could have done more to advance an understanding of the insidious effects of misogyny and femmephobia.

In summary, The Fruit Machine documentary serves an important and critical role: increasing public awareness about this troubled part of Canadian history. Its brevity precludes a larger, more encompassing and complex telling of a story that spanned more than fifty years. The stories of the intimate partners of these individuals, and the stories of the soldiers, police officers, and civil servants who continued to serve but suffered the horrors of the Purge campaign remain untold (Gouliquer and Poulin 2005; Poulin 2001). Nonetheless, the documentary can be used to facilitate a deeper understanding of, and stimulate discussions with regard to, men-dominated institutions and their foundational and problematic pro-masculine, heteronormative, anti-feminine, and misogynist structures of power. The Fruit Machine documentary could not do it all, but perhaps, it will inspire a mini-series! 


\section{References}

Blair, Karen L., and Rhea Ashley Hoskin. 2015.

"Experiences of Femme Identity: Coming out, Invisibility and Femmephobia.” Psychology \& Sexuality 6 (3): 229-44. https://doi.org/ 10.1080/19419899.2014.921860.

Gouliquer, Lynne. 2000. "Negotiating Sexuality: Lesbians in the Canadian Military." In Women's Bodies/ Women's Lives: Health, Well-Being and Body Image, edited by Baukje Miedema, Janet Mary Stoppard, and Vivienne Anderson, 254-76. Toronto: Sumach Press.

Gouliquer, Lynne. 2011. "Soldiering in the Canadian Forces: How and Why Gender Counts!” PhD Thesis, McGill University, Montreal.

Gouliquer, Lynne, and Carmen Poulin. 2005. "For Better and for Worse: Psychological Demands and Structural Impacts on Gay Servicewomen in the Military and Their Long-Term Partners." In Doing Ethnography: Studying Everyday Life, edited by Dorothy Pawluch, William Shaffir, and Charlene Miall, 323-35. Toronto: Canadian Scholars' Press.

Hoskin, Rhea Ashley. 2017. "Femme Theory: Refocusing the Intersectional Lens." Atlantis: Critical Studies in Gender, Culture \& Social Justice 38 (1): 95109.

Park, Rosemary E. 1994. "Opening the Canadian Forces to Gays and Lesbians: An Inevitable Decision but Improbable Reconfiguration.” In Gays and Lesbians in the Military: Issues, Concerns, and Contrasts, edited by Wilbur J. Scott and Sandra Carson Stanley, 165-79. New York: Aldine de Gruyter.

Poulin, Carmen. 2001. "The Military Is the Wife and I Am the Mistress: Partners of Lesbians in the Canadian Military." Atlantis: Critical Studies in Gender, Culture \& Social Justice 26 (1): 65-76.

Poulin, Carmen, and Lynne Gouliquer. 2012. "Clandestine Existences and Secret Research: Eliminating Official Discrimination in the Canadian
Military and Going Public in Academia." Journal of Lesbian Studies 16 (1): 54-64. https://doi.org/ 10.1080/10894160.2011.557643.

Poulin, Carmen, Lynne Gouliquer, and Jessica McCutcheon. 2018. "Violating Gender Norms in the Canadian Military: The Experiences of Gay and Lesbian Soldiers." Sexuality Research \& Social Policy: A Journal of the NSRC 15 (1): 60-73. https://doi.org/ $10.1007 / \mathrm{s} 13178-017-0304-\mathrm{y}$.

Poulin, Carmen, Lynne Gouliquer, and Jennifer Moore. 2009. "Discharged for Homosexuality from the Canadian Military: Health Implications for Lesbians." Feminism \& Psychology 19 (4): 496-516. https://doi.org/10.1177/0959353509342772. 